Ana Cristina A. da Silva, Edinardo F. F. Matias, Janaína E. Rocha, Ana Carolina Justino de Araújo, Thiago S. de Freitas, Fábia F. Campina, Maria do S. Costa, Luiz E. Silva, Wanderlei do Amaral, Beatriz Helena L. N. S. Maia, Aurea P. Ferriani, Camila F. Bezerra, Marcello Iriti* and Henrique D. M. Coutinho*

\title{
Gas chromatography coupled to mass spectrometry (GC-MS) characterization and evaluation of antibacterial bioactivities of the essential oils from Piper arboreum Aubl., Piper aduncum L. e Piper gaudichaudianum Kunth
}

https://doi.org/10.1515/znc-2020-0045

Received February 17, 2020; accepted May 29, 2020; published online July 16, 2020

\begin{abstract}
The objective of this study was to determine the chemical profile and to evaluate the antibacterial activity of the essential oils of Piper species and modulation of the antibiotic activity, using the microdilution method to determine the minimum inhibitory concentration. The chemical components were characterized by gas chromatography coupled to mass spectrometry, which revealed $\beta$-copaen-4$\alpha$-ol (31.38\%), spathulenol (25.92\%), and germacrene B (21.53\%) as major constituents of the essential oils of Piper arboreum, Piper aduncum, and Piper gaudichaudianum, respectively. The essential oils analyzed in this study did not
\end{abstract}

*Corresponding authors: Marcello Iriti, Departement of Agricultural and Environmental Sciences, Milan State University, via G. Celoria 20133, Milan, Italy. E-mail: marcello.iriti@unimi.it, and Henrique D. M. Coutinho, Laboratório de Microbiologia e Biologia MolecularLMBM, Universidade Regional do Cariri-URCA, Av. Cel. Antônio Luiz, 1161, Pimenta, CEP 63105-000, Crato, CE, Brazil. E-mail address: hdmcoutinho@urca.br

Ana Cristina A. da Silva, Edinardo F. F. Matias, Janaína E. Rocha, Ana Carolina Justino de Araújo, Thiago S. de Freitas, Fábia F. Campina and Maria do S. Costa: Regional University of Cariri (URCA), Crato, CE, Brazil, E-mail: ana.cristina.erivanda@gmail.com (A.C.A. da Silva), effm_biologia@hotmail.com (E.F.F. Matias), janainaesmeraldo@gmail.com (J.E. Rocha), thiagocrato@hotmail.com (T.S. de Freitas), fabiacampina@gmail.com (F.F. Campina), corrinha_live@yahoo.com.br (M.S. Costa)

Luiz E. Silva, Wanderlei do Amaral, Beatriz Helena L. N. S. Maia and Aurea P. Ferriani: Federal University of Paraná (UFPR), Curitiba, PR, Brazil, E-mail: luiz_everson@yahoo.de (L.E. Silva), wdoamaral@hotmail.com (W. Amaral), bhsalesmaia@gmail.com (B.H.L.N.S. Maia), aurea.portes@hotmail.com (A.P. Ferriani) Camila F. Bezerra: Federal University of Pernambuco (UFPE), Recife, PE, Brazil, E-mail: camilawasidi@gmail.com present a clinically relevant activity against standard and multiresistant Escherichia coli. However, in the case of multiresistant Staphylococcus aureus, there was a significant activity, corroborating with reports in the literature, where Gram-positive bacteria are more susceptible to antimicrobial activity. The essential oils modulated the effect of the antibiotics norfloxacin and gentamicin, having on the latter greater modulating effect; however, for erythromycin, no statistically significant effect was observed. In conclusion, the results obtained in this study demonstrated that the essential oils of the analyzed Piper species present an inhibitory effect against $S$. aureus and modulate antibiotic activity, most of which presents synergistic activity.

Keywords: antibacterial activity; essential oil; modulation; Piperaceae.

\section{Introduction}

Many medicinal plants have a large amount of bioactive compounds, such as phenolic compounds, terpenoids, nitrogen compounds, vitamins, and several other secondary metabolites, and since the beginning of mankind, they have been used for therapeutic purposes [1-3]. Studies show that several phytochemicals present in medicinal plants have anti-inflammatory, antitumoral, antibacterial, or viral action [4].

The Piperaceae family encompasses 12 genera with about 1100 species. The genus Piper widely distributed in subtropical regions is known for its aromatic herbs [5]. Many species of this genus produce essential oils which contain monoterpenes (germacrene A, $\alpha$-pinene), sesquiterpenes (germacrene $\mathrm{B}$, germacrene $\mathrm{D}, \alpha$-humulene, $\beta$-copaen-4- $\alpha$-ol), phenylpropanoids (humulene epoxide 
II, muurola-4,10(14)-dien-1- $\beta$-ol), aldehydes (cinnamaldehyde), ketones, and long chain alcohols [6].

The species Piper arboreum Aubl., popularly known as "pau-de-angola", "jaborandi”, chilli pepper, has antifungal, trypanocidal, antibacterial, and antioxidant activities [7,8]. Piper aduncum L., popularly known as "jaborandi do mato", monkey pepper, "jaboti” [9] herb possesses antifungal [10], antiprotozoal [11], and insecticide activities [12]. Piper gaudichaudianum Kunth is popularly known as "pariparoba" or "jaborandi" [13], its leaves are used in folk medicine to relieve toothache. Other studies report biological activities such as fungicide [14], insecticidal, anti-inflammatory, larvicidal, and analgesic effects $[15,16]$.

Bacterial resistance is considered one of the most important public health problems [17]. It is characterized by mechanisms by which bacteria decrease the action of antibiotic agents and may present in a natural or acquired form [18].

Due to the great difficulty found in the treatment of infections caused by multiresistant bacteria, the need for new antimicrobial substances that are effective in the fight against microorganisms is well known. Based on this premise, this work aims to evaluate the antimicrobial and modulating effects of the essential oils of $P$. arboreum, $P$. aduncum and $P$. gaudichaudianum.

\section{Material and methods}

\section{Collection and identification of plant material}

The fresh leaves of the plants were collected (summer of 2017) in the Biological Reserve of Bom Jesus Biological Reserve, at Vale do Ribeira, Guaraqueçaba-PR, Brazil. A voucher specimen of each plant was deposited in the Botanical Museum of Curitiba and in the Herbarium of the Faculdades Integradas Espírita with numbers of 396412 (P. arboreum), 396411 (P. aduncum), and 396403 (P. gaudichaudianum). This research was registered with an SISGEN N. A216E5A and an SISBIO N. 49770-1.

\section{Extraction and chemical characterization of the essential oils}

The extraction of the essential oils was performed by the hydrodistillation method using the Clevenger-type apparatus. Fresh leaves of each plant $(50 \mathrm{~g})$ were crushed and placed in a glass flask with $1.0 \mathrm{~L}$ of distilled water, remaining in the boil for $4.5 \mathrm{~h}$ for extraction [19]. The leaves were dried with an electric dryer (FANEM-Mod. 320 SE) with air circulation at $40^{\circ} \mathrm{C}$ for $24 \mathrm{~h}$. To determine the essential oil content in dry basis, the total mass of each essential oil obtained was considered in relation to the amount of the dry mass of the botanical material used in the extraction. After extraction, the samples were collected with a precision pipette and conditioned in a freezer until the analysis. Each oil was named as follow: essential oil of P. arboreum Aubl. (EOPar), essential oil of $P$. aduncum L. (EOPad), and essential oil of $P$. gaudichaudianum Kunth (EOPg).

The chemical constituents of the essential oils were identified by gas chromatography coupled to mass spectrometry (GC-MS). The essential oils were diluted to a concentration of $1 \%$ in dichloromethane and 1.0 $\mu \mathrm{L}$ of the solution was injected with a 1:20 flow split into a chromatograph (Agilent 6890-Palo Alto, CA) coupled to a mass selective detector (Agilent 5973N-Palo Alto, CA). The injector was maintained at $250^{\circ} \mathrm{C}$, and the constituents were isolated in an HP5MS capillary column (5\%-phenyl-95\%-dimethylpolysiloxane, $30 \mathrm{~m} \times 0.25 \mathrm{~mm} \times 0.25 \mu \mathrm{m})$ using helium as carrier gas $\left(1.0 \mathrm{~mL} \mathrm{~min}{ }^{-1}\right)$. The oven temperature was programmed from 60 to $240^{\circ} \mathrm{C}$ at a rate of $3^{\circ} \mathrm{C} \mathrm{min}^{-1}$. The mass detector was operated in electronic ionization mode $(70 \mathrm{eV})$, at a rate of $3.15 \mathrm{~s}^{-1}$ sweeps, and a mass band of 40 to $450 \mathrm{u}$. The transfer line was maintained at $260^{\circ} \mathrm{C}$, with ion source at $230^{\circ} \mathrm{C}$ and analyzer (quadrupole) at $150^{\circ} \mathrm{C}$.

For quantification, the diluted samples were injected into a chromatograph (Agilent 7890A-Palo Alto, CA) equipped with a flame ionization detector (FID), operated at $280^{\circ} \mathrm{C}$. The same column and analytical conditions described above were employed, except for the carrier gas, which was hydrogen, at a flow rate of $1.5 \mathrm{~mL} \mathrm{~min}^{-1}$. The percentage composition was obtained by the electronic integration of the FID signal by dividing the area of each component by the total area (area $\%)$.

The identification of the chemical constituents was performed by comparing their mass spectra with those of spectral libraries $[20,21]$ and by their linear retention indexes, calculated from the injection of a homologous series of hydrocarbons $\left(\mathrm{C}_{7}-\mathrm{C}_{26}\right)$ and compared with data from the literature [22].

\section{Antibiotics, culture media, and microorganisms}

The liquid antibiotics gentamicin and amikacin were obtained from LaborClin, Brazil. Heart Infusion Agar (HIA) and Brain Heart Infusion (BHI) culture media were acquired from HIMEDIA. The microorganisms used in the tests were provided by the Laboratory of Microbiology and Molecular Biology of the Regional University of Cariri. The following standard and resistant bacterial strains were used throughout this study: Escherichia coli ATCC 25922, E. coli 06, Staphylococcus aureus ATCC 25923, and S. aureus 10.

\section{Preparation of test solutions}

The test solutions were prepared using $10 \mathrm{mg}$ of each oil diluted in $0.5 \mathrm{~mL}$ of dimethyl sulfoxide. Each solution was diluted to a final concentration of $1024 \mu \mathrm{g} / \mathrm{mL}$. The solutions of the oils at this concentration were used in the antibacterial and modulation tests. The antibiotics used in the tests were also prepared at an initial concentration of $1024 \mu \mathrm{g} / \mathrm{mL}$.

\section{Determination of the minimum inhibitory concentration (MIC) by direct contact}

Bacterial samples were seeded in Petri dishes containing HIA and placed in an oven at $37^{\circ} \mathrm{C}$ for $24 \mathrm{~h}$ to grow. After this period, the 
samples were collected and diluted in test tubes in triplicate. Then, the turbidity of the solution was determined according to the McFarland scale.

To evaluate the antibacterial activity, $100 \mu \mathrm{L}$ of the inoculum solution was added to each well of the microdilution plate. Then, the treatments were performed using $100 \mu \mathrm{L}$ of each oil per column at final concentrations ranging from 512 to $0.5 \mu \mathrm{g} / \mathrm{mL}$. Of note, all treatments were performed in triplicate. The plates were taken to an oven at $37^{\circ} \mathrm{C}$ for $24 \mathrm{~h}$. Then, each well was added with $20 \mu \mathrm{L}$ of resazurin (a colorimetric indicator) and $1 \mathrm{~h}$ later the MIC was determined by ocular observation [23,24].

The antibiotic activity modulation assay was performed using amikacin and gentamicin according to the method described by [25] Briefly, test tubes were added with $150 \mu \mathrm{L}$ of the bacterial suspension in a solution containing $10 \% \mathrm{BHI}$ medium and the essential oils at subinhibitory concentrations (MIC/8). Control tubes were prepared using $150 \mu \mathrm{L}$ of the bacterial suspension in a solution containing $10 \%$ BHI medium. Then, $100 \mu \mathrm{L}$ of these solutions were transferred to corresponding wells in the plate and $100 \mu \mathrm{L}$ of the antibiotic were added to the first well and serially diluted. The treatments were performed in triplicate, and the MICs were determined as described above.

\section{Statistical analysis}

The results were expressed as mean \pm standard deviation and differences were evaluated through analysis of variance followed by Bonferroni posttests using GraphPad Prism 6.0 software. Results with $p<0.05$ were considered as statistically significant.

\section{Results}

\section{Chemical composition}

The relative amounts of the individual components were calculated based on the GC peak area (FID response), which those having a percentage above $10 \%$ were considered as major components.

The essential oil of $P$. arboreum had a yield of $0.23 \%$. A total of 15 components were identified, representing $83.58 \%$ of the composition (Table 1), of which, $5.57 \%$ are monoterpenes oxygenated, $44.57 \%$ are sesquiterpenes oxygenated, $33.43 \%$ are sesquiterpenes nonoxygenated, having as main constituents $\beta$-copaen-4- $\alpha$-ol: $31.38 \%$, muurola-4,10-(14)-diene-1- $\beta$-ol: $17.32 \%$.

The volatile oil of $P$. aduncum L. was isolated in $0.35 \%$ and presented high concentration of sesquiterpenes nonoxygenated (45.45\%) and sesquiterpenes oxygenated (44.52\%; Table 1), with spathulenol as the major compound $(25.92 \%)$. In addition, $\beta$-macrocarpene (9.52\%), $\alpha$-humulene (5.33\%) aromadendrene (5.61), and $\beta$-copaen-4- $\alpha$-ol $(5.45 \%)$, were also found in considerable yield.
Distillation of the essential oil of $P$. gaudichaudianum presented a yield of $0.56 \%$. Twenty-two components were identified, representing $87.04 \%$ of the composition (Table 1), of these $3.96 \%$ are monoterpenes hydrocarbon, $67.26 \%$ sesquiterpenes nonoxygenated and $15.82 \%$ sesquiterpenes oxygenated, having as main constituent germacrene B: $21.53 \%$.

\section{Determination of minimum inhibitory concentration}

In microdilution tests, EOPar showed MICs $=512 \mu \mathrm{g} / \mathrm{mL}$ against standard (ATCC 6538) S. aureus, $128 \mu \mathrm{g} / \mathrm{mL}$ against multiresistant $S$. aureus, and $\geq 1024 \mu \mathrm{g} / \mathrm{mL}$ against standard (ATCC 25922) and resistant E. coli. The EOPad had MIC $=512 \mu \mathrm{g} / \mathrm{mL}$ against standard S. aureus, $16 \mu \mathrm{g} / \mathrm{mL}$ against multi-resistant $S$. aureus, $\geq 1024 \mu \mathrm{g} / \mathrm{mL}$ against standard $E$. coli and $813 \mu \mathrm{g} / \mathrm{mL}$ against resistant $E$. coli. The EOPg had MIC $=813 \mu \mathrm{g} / \mathrm{mL}$ against standard $S$. aureus and $\geq 1024 \mu \mathrm{g} / \mathrm{mL}$ against resistant $S$. aureus and standard and resistant $E$. coli (Table 2).

\section{Modulation of antibiotic activity}

In the evaluation of the modulating effect, the combination of the EOPar (Figure 1) with the antibiotics norfloxacin and gentamicin caused decrease of the MIC against $S$. aureus 10 , indicating synergism in the association of these treatments, whereas for E. coli 06 only synergism was observed in the combination with gentamicin, norfloxacin did not show a significant effect (Figure 2).

The combination of $P$. aduncum essential oil with norfloxacin resulted in increased MIC, gentamicin, and decreased MIC indicating respectively antagonism and synergism against $S$. aureus 10 and E. coli 06 (Figures 3 and 4).

The association of the EOPg with the drugs norfloxacin and gentamicin presented a synergistic effect against S. aureus 10 causing a decrease in MIC (Figure 5) and an antagonistic effect against $E$. coli 06, provoking an increase in MIC (Figure 6). The antibiotic erythromycin did not present significant results against any of the strains used in this study.

\section{Discussion}

Essential oils are substances derived from medicinal herbs that are widely used in the pharmaceutical, food, 
Table 1: Essential oil composition of leaves of Piper arboreum, Piper aduncum, and Piper gaudichaudianum.

\begin{tabular}{|c|c|c|c|}
\hline Compounds & $\begin{array}{l}\text { EOPar } \\
\text { RI (\%) }\end{array}$ & $\begin{array}{l}\text { EOPad } \\
\text { RI (\%) }\end{array}$ & $\begin{array}{r}\text { EOPg } \\
\text { RI (\%) }\end{array}$ \\
\hline \multicolumn{4}{|l|}{ Monoterpenes hydrocarbon } \\
\hline$\alpha$-pinene & - & - & $935(2.19)$ \\
\hline \multicolumn{4}{|l|}{ Monoterpenes oxygenated } \\
\hline Khusimone & $1600(2.48)$ & - & \\
\hline \multicolumn{4}{|l|}{ Sesquiterpenes oxygenated } \\
\hline (E)-Caryophyllene & $1426(3.61)$ & $1426(2.46)$ & $1426(3.75)$ \\
\hline$\delta$-cadinene & $1531(1.02)$ & - & - \\
\hline$\alpha$-amorphene & $1488(2.09)$ & - & \\
\hline$\delta$-selinene & $1493(1.03)$ & $(9.52)$ & $1498(1.65)$ \\
\hline 4,5-di-epi-Aristolochene & - & - & $1470(1.27)$ \\
\hline Allo-aromadendrene & - & $(5.61)$ & $1467(2.47)$ \\
\hline Amorpha-4,7(11)-diene & - & - & $1477(2.86)$ \\
\hline Aromadendrene & - & 1445 (1.44) & \\
\hline Bicyclogermacrene & - & 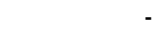 & $1504(2.57)$ \\
\hline Cubebol & - & $1522(3.28)$ & \\
\hline$\alpha$-calacorene & - & - & $1551(3.5)$ \\
\hline$\beta$-calacorene & - & - & $1572(1.98)$ \\
\hline$\delta$-cadinene & - & $1530(4.07)$ & $1530(9.39)$ \\
\hline$\alpha$-copaene & - & - & $1381(4.36)$ \\
\hline 4-epi-cis-dihidroagarofuran & - & - & $1508(2.99)$ \\
\hline$\beta$-elemene & - & - & $1438(6.1)$ \\
\hline$\gamma$-elemene & - & - & $1397(5.24)$ \\
\hline$(E, E)-\alpha$-farnesene & - & $\cdot$ & $1513(1.92)$ \\
\hline Germacrene B & $1561(2.44)$ & - & $1566(21.53)$ \\
\hline Germacrene D & - & $1493(3.13)$ & $1487(1.2)$ \\
\hline Heptan-2-one-6-methyl-6-(3-methylphenyl) & $1645(1.63)$ & - & \\
\hline$\alpha$-humulene & - & $1460(5.33)$ & $1460(3.67)$ \\
\hline$\beta$-macrocarpene & - & $1499(9.52)$ & - \\
\hline$\alpha$-murolene & - & $1506(1.09)$ & \\
\hline \multicolumn{4}{|l|}{ Sesquiterpenes non-oxygenatedrowhead } \\
\hline$\beta$-copaen-4- $\alpha$ ol & $1593(31.38)$ & $1588(5.45)$ & $1587(2.06)$ \\
\hline Cedrol & - & $1604(2.12)$ & \\
\hline Caryophyllene oxide & - & - & $1592(1.96)$ \\
\hline Ledol & 1612 & $(2.66)$ & - \\
\hline Cubenol & 1637 & $(2.20)$ & \\
\hline Eudesm-7(11)-em-4-ol & $1690(1.03)$ & - & - \\
\hline 7-acetoxy-elema-1,3-dien-8-8-ol & $1792(2.06)$ & $\cdot$ & - \\
\hline Germacra-4(15),5,10(14)-trien-1- $\alpha$-ol & $1683(1.5)$ & $(1.05)$ & - \\
\hline Intermedeol & $1666(1.75)$ & - & \\
\hline (E)-nerolidol & - & - & $1569(3.26)$ \\
\hline Pogostol & - & $1650(3.15)$ & - \\
\hline Muurola-4,10(14)-dien-1- $\beta$-ol & $1640(17.32)$ & $(1.97)$ & 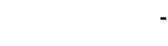 \\
\hline$\beta$-himachalene oxide & $1619(6.16)$ & - & - \\
\hline Spathulenol & 1587 (8.08) & (25.92) & \\
\hline
\end{tabular}

$\mathrm{RI}=$ retention index; EOPar $=$ Piper arboreum Aubl.; EOPad = Piper aduncum L.; EOPg = Piper gaudichaudianum Kunth.

cosmetics, sanitary, and perfumery industries. The chemical composition of these oils is a mixture of several components in different concentrations, most of which are characterized by the presence of two or three components in high concentrations (20-70\%) and other components in a lower concentration. The major compounds determine the biological properties of essential oils [26].
The chemical composition of essential oils differs between plants of the same species. The EOPg had as main constituent germacrene B (21.53\%). This result is a disagreement with previous studies. According to Péres et al. [27], the main compounds of $P$. gaudichaudianum essential oil were (E)-nerolidol (22.4\%) and $\alpha$ - humulene $(16.5 \%)$. 
Table 2: Minimum inhibitory concentration (MIC) of the essential oils $(\mu \mathrm{g} / \mathrm{mL})$.

Essential oil

Bacteria

$\begin{array}{llll}\text { S. A. ATCC } 6538 & \text { E. C. ATCC } 25922 & \text { S. A. } 10 & \text { E. C. } 06\end{array}$

\begin{tabular}{lrrrr}
\hline EOPar & 512 & $\geq 1024$ & 128 & $\geq 1024$ \\
EOPad & 512 & $\geq 1024$ & 16 & 813 \\
EOPg & $\geq 1024$ & $\geq 1024$ & 813 & $\geq 1024$ \\
\hline
\end{tabular}

ATCC = standard strain; S. A. = Staphylococcus aureus;

E. C. = Escherichia coli; EOPar $=$ essential oil of Piper arboretum Aubl.; EOPad = essential oil of Piper aduncum L.; EOPg = essential oil of Piper gaudichaudianum Kunth.

The main components found in the EOPad also differ with results obtained in previous studies for this species. Almeida et al. [28] identified dillapiole (76\%) as the main component of the EOPad, diverging with the result found in this study; however, it resembles the result found by Schindler and Heinzmann [29] who identified $\beta$-copaen-4- $\alpha$-ol among the major constituents in the EOPg, a species that is part of the same genus of P. aduncum.

The component identified in this study in the highest concentration of $P$. arboreum essential oil, $\beta$-copaen-4- $\alpha$-ol (31.38\%) diverges with that found by Silva et al. [30], which identified bicyclogermacrene (28.7\%) as the major component, in this same study $\beta$-copaen-4- $\alpha$-ol was also identified, being characterized as the second component with the highest concentration.

The chemical composition of the essential oils of the species used in this study differs from the data found in the literature. Chemical variability may result from environmental and/or ecological selection pressure, characterizing a chemical adjustment to prevailing environmental conditions [31].

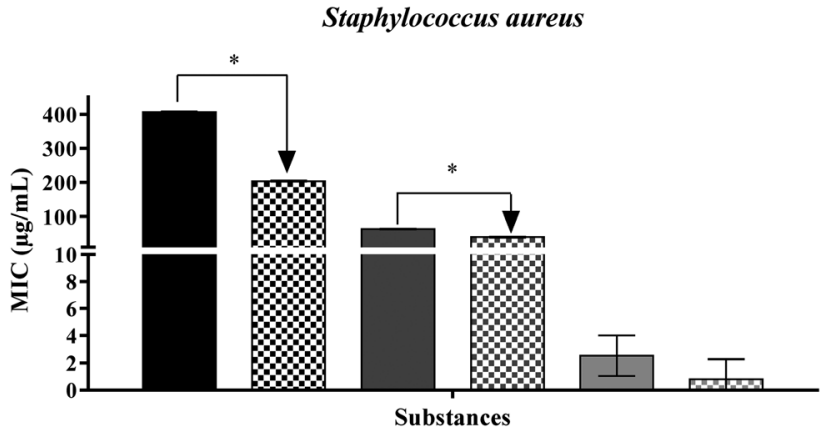

Escherichia coli

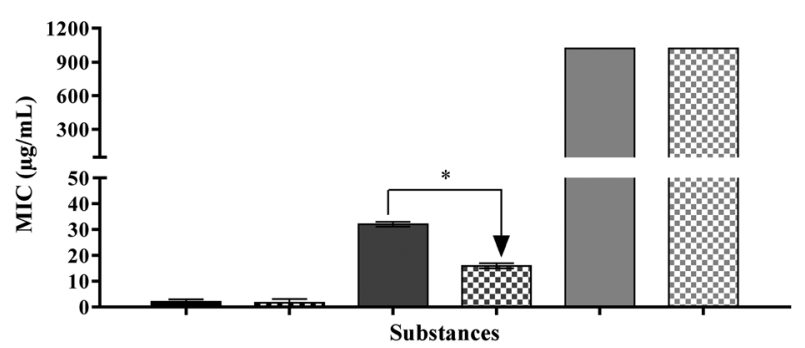

Staphylococcus aureus

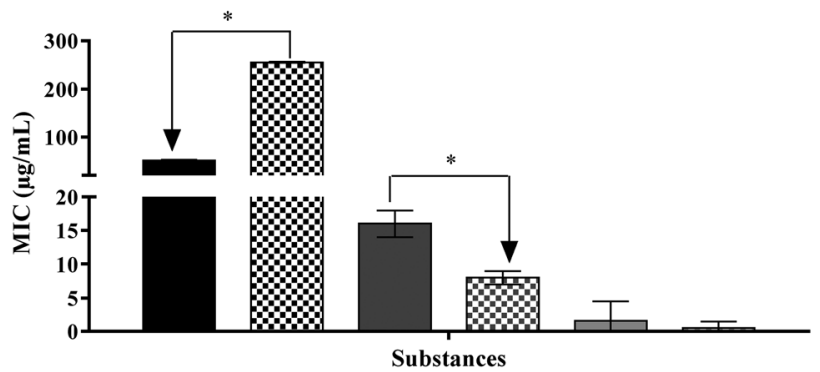

Norfloxacin Control EOPar + Norfloxacin Gentamycin Control EOPar + Gentamycin $\square$ Erythromycin Control EOPar + Erythromycin
Figure 1: Modulatory effect of essential oil from Piper arboreum (EOPar) in the antibiotic activity of norfloxacin, gentamycin, and erytromycin against strains of Staphylococcus aureus 10.

Figure 2: Modulatory effect of essential oil from Piper arboreum (EOPar) in the antibiotic activity of norfloxacin, gentamycin, and erytromycin against strains of Escherichia coli 06.
Norfloxacin Control
EOPad + Norfloxacin
Gentamycin Control
EOPad + Gentamycin
$\square$ Erythromycin Control
$\square$ EOPad + Erythromycin

Figure 3: Modulatory effect of essential oil from Piper aduncum (EOPad) in the antibiotic activity of norfloxacin, gentamycin, and erytromycin against strains of Staphylococcus aureus 10. 


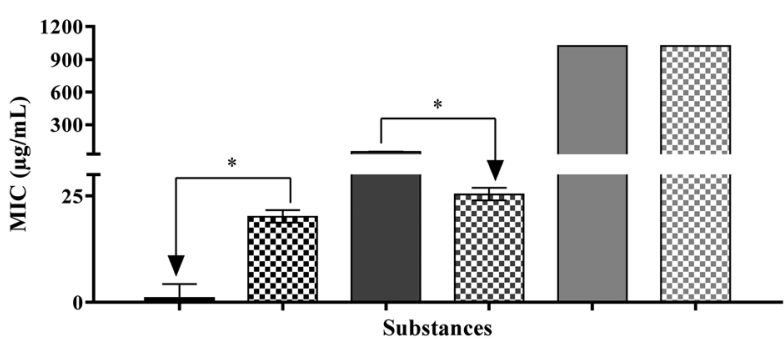

Staphylococcus aureus

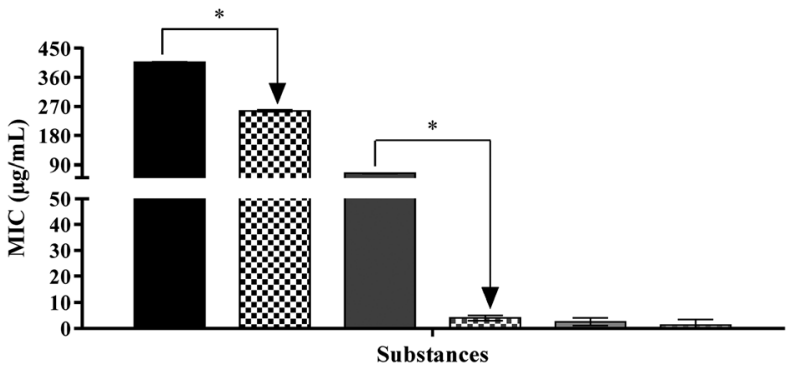

Escherichia coli

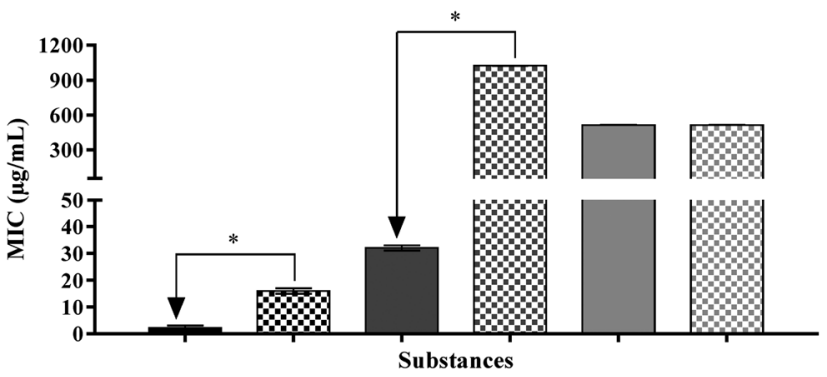

The essential oils showed low activity against $E$. coli, this result can be justified by the presence of an outer membrane in this microorganism, which makes difficult the passage of the components present in the essential oils, as well as of other antimicrobials, thus hampering their action [32,33].

Clinically relevant activity of essential oils against multidrug-resistant $S$. aureus has been observed, corroborating with reports found in the literature that indicate that Gram-positive bacteria are more susceptible to essential oils than Gram-negative bacteria [34]. This result diverges with previous study carried out with essential oils of Piper species, where they did not find significant activity against S. aureus [35].

In the combination of the compounds with antibiotics, it was possible to observe the synergism of the essential oil of $P$. arboreum against $S$. aureus and $E$. coli combined with gentamicin and norfoxacin against $S$. aureus. The efflux
Norfloxacin Control

DOPad + Norfloxacin

$\square$ Gentamycin Control

EOPad + Gentamycin

$\square$ Erythromycin Control

EOPad + Erythromycin
Figure 4: Modulatory effect of essential oil from Piper aduncum (EOPad) in the antibiotic activity of norfloxacin, gentamycin, and erytromycin against strains of Escherichia coli 06.
Figure 5: Modulatory effect of essential oil from Piper gaudichaudianum (EOPg) in the antibiotic activity of norfloxacin, gentamycin, and erytromycin against strains of Staphylococcus aureus 10.
Norfloxacin Control EO EOPg + Norfloxacin $\square$ Gentamycin Control EOPg + Gentamycin $\square$ Erythromycin Control EOPg + Erythromycin
Figure 6: Modulatory effect of essential oil from Piper gaudichaudianum (EOPg) in the antibiotic activity of norfloxacin, gentamycin, and erytromycin against strains of Escherichia coli 06.

pumps present on the plasma membrane of $E$. coli [36] may be related to the indifferent result found in combination with norfloxacin. Synergism is the combination of drugs or natural compounds, which have the ability to act in several sites of the microbial cell, potentializing the agonist's action in the test [25].

The antagonism observed in the combination of the EOPad with norfloxacin (against $S$. aureus and E. coli) and EOPg (against E. coli) can be explained by binding of the components at binding sites for the antibiotic, or chelation of the drug causing a decrease in its action spectrum [37], mechanisms may also explain the antagonism between EOPg and gentamicin against E. coli. Synergism observed with gentamicin can be explained by the efficacy of aminoglycosides against Gram-negative and its ability to act in conjunction with other drugs or natural products against Gram-positive [38]. 
The composition of the cell wall of Gram-positive microorganisms is thicker, with more peptides, making them more susceptible to antibiotics than Gram-negative microorganisms [39]. The synergism between the EOPg and the antibiotics norfloxacin and gentamicin against the Gram-positive bacteria $S$. aureus may be due to changes in the permeability of the wall and cell membrane of the microorganism due the alteration in the lipid bilayer, which may facilitate the passage of drugs acting inside the cell, such as the aminoglycosides and norfloxacin [40].

The observed indifference in EOPar, EOPad, and EOPg modulations with erythromycin can be attributed to the resistance mechanisms that these strains have developed for this antibiotic, such as the efflux pumps present in E. coli [41].

\section{Conclusion}

The results obtained in this study showed that the essential oils of $P$. arboreum, $P$. aduncum, and $P$. gaudichaudianum have an antibacterial effect against $S$. aureus and interfere with the action of antibiotics. These findings become important in the search for new effective therapies for infections triggered by multiresistant bacteria.

\section{Subtitles and abbreviations lists}

$\begin{array}{ll}\text { ATCC } & \text { American Type Culture Collection; } \\ \text { E. C. } & \text { Escherichia coli; } \\ \text { EOPad } & \text { Essential Oil of Piper aduncumL.; } \\ \text { EOPar } & \text { Essential Oil of Piper arboretumAubl.; } \\ \text { EOPg } & \text { Essential Oil of Piper gaudichaudianum Kunth.; } \\ \text { MIC } & \text { Minimum Inhibitory Concentration; } \\ \text { RI } & \text { Retetion Index; } \\ \text { S. A. } & \text { Staphylococcus aureus; }\end{array}$

Author contribution: All the authors have accepted responsibility for the entire content of this submitted manuscript and approved submission.

Research funding: None declared.

Conflict of interest statement: The authors declare no conflicts of interest regarding this article.

\section{References}

1. Kamiloglu S, Capanoglu E, Yilmaz O, Duran AF, Boyacioglu D. Investigating the antioxidant potential of Turkish herbs and spices. Qual Assur Saf Crop Food 2014;6:151-8.
2. Karadeniz A, Cinbilgel I, Gun SS, Cetin A. Antioxidant activity of some Turkish medicinal plants. Nat Prod Res 2015;29:2308-12.

3. Zheng W, Wang SY. Antioxidant activity and phenolic compounds in selected herbs. J Agric Food Chem 2001;49:5165-70.

4. Sala A, Recio MDC, Giner RM, Máñez S, Tournier H, Schinella G, et al. Anti-inflammatory and antioxidant properties of Helichrysum italicum. J Pharm Pharmacol 2002;54:365-71.

5. Guerrini A, Saccheti G, Rossi D, Paganetto G, Muzzoli M, Andreotti E, et al. Bioactivities of Piper aduncum L. and Piper obliquum Ruiz \& Pavon (Piperaceae) essential oil from Easter Ecuador. Environ Toxicol Pharmacol 2002;27;39-48.

6. Cysne JB, Canuto KM, Pessoa ODL, Nunes EP, Silveira ER. Leaf essential oils of four Piper species from the state of Cearánortheast of Brazil. J Baz Chem Soc 2005;16:1378-81.

7. Regasini LO, Cotinguiba F, Passerini GD, Bolzani VS, Cicarelli RMB, Kato MJ, et al. Trypanocidal activity of Piper arboreum and Piper tuberculatum (Piperaceae). Rev Bras Farmacog 2009a;19: 199-03.

8. Regasini LO, Cotinguiba V, Morandim AA, Kato MJ, Scorzoni L, Mendes-Giannini MJS, et al. Antimicrobial activity of Piper arboreum and Piper tuberculatum (Piperaceae) against opportunistic yeasts. Afr J Biotechnol 2009b;8:2866-70.

9. Botsaris AS. As fórmulas mágicas das plantas: como utilizar a fitoterapia no tratamento de doenças simples, 2 nd ed. Rio de Janeiro: Record: Nova Era; 1997.

10. Valadares ACF, Alves CCF, Alves JM, De Deus IPB, Oliveira-Filho JG, Santos TCL, et al. Essential oils from Piper aduncum inflorescences and leaves: chemical composition and antifungal activity against Sclerotinia sclerotiorum. An Acad Bras Ciênc 2018;90:2691-9.

11. Villamizar LH, Das Graças CM, Andrade J, Teixeira ML, Soares MJ. Linalool a Piper aduncum essential oil component, has selective activity against Trypanosoma cruzi trypomastigote forms at $4^{\circ} \mathrm{C}$. Mem Inst Oswaldo Cruz 2017;112:131-9.

12. Mamood SNH, Hidayatulfathi O, Budin SB, Ahmad Rohi G. The formulation of the essential oil of Piper aduncum Linnaeus (Piperales: Piperaceae) increases its efficacy as an insect repellent. B Entomol Res 2017;107:49-57.

13. Guimarães EF, Valente MC. Piperáceas-Piper. Flora llustrada Catarinense, Itajaí: Santa Catarina; 2001:104 p.

14. Lago JHG, Ramos CS, Casanova DC, Morandim A, Bergano DC, Cavalheiro AJ, et al. Benzoic acid derivatives from Piper species and their fungitoxic activity against Clodosporium cladosporioides and C. shaerospermum. J Nat Prod 2004;67: 1783-8.

15. Morais DL, Kaplan MAC, Santos PO, Guimarães EF. Estudos fitoquímicos e farmacológicos de Piper gaudichaudianum Kunth (Piperaceae). Rev Bras Farmacog 2007;82:29-32.

16. Puhl MC, Cortez DA, Ueda-Nakamura T, Nakamura CV, Filho BP. Antimicrobial activity of Piper gaudichaudianum Kuntze and its synergism with differents antibiotics. Molecules 2011;16:992538.

17. Loureiro RJ, Roque F, Rodrigues AT, Herdeiro MT, Ramalheira E. O uso de antibióticos e as resistências bacterianas: breves notas sobre a sua evolução. Rev Port Saúde Púb 2016;34:77-84.

18. Kohl T, Pontarolo GH, Pedrassani D. Resistência antimicrobiana de bactérias isoladas de amostras de animais atendidos em hospital veterinário. Saúde Meio Ambiente 2016;5:115-27.

19. Wasicky R. Uma modificação do aparelho de clevenger para extração de óleos essenciais. Rev Fac Farm e Bioq 1963;1:77-81. 
20. Linstrom PJ, Mallard WG, editors. NIST Chemistry Webbook. Available from: http://webbook.nist.gov [Accessed at June 2016].book-chapter.

21. Wiley Registry of Mass Spectral Data, 6th ed. New York: WileyInterscience; 1994.

22. Adams RP. Identification of essential oil components by gas chromatography/mass spectroscopy. Carol Stream: Allured Publishing Corporation; 2007.

23. Javadpour MM, Juban MM, LO WC, Bishop SM, Alberty JB, Mann CM, et al. A new method for determine the minimum inhibitory concentration of essential oils. J Appl Microbiol 1996;84:538-44.

24. NCCLS. Methods for dilution antimicrobial susceptibility tests for bacteria that grow aerobically. USA: Wayne, NIH; 2003.

25. Coutinho HDM, Costa JGM, Siqueira JP, Jr., Lima EO. In vitro antistaphylococcal activity of Hyptis martiusii Benth against methicillin-resistant Staphylococcus aureus-MRSA strains. Braz J Pharmacogn 2008a;18:670-5.

26. Palazzolo E, Laudicina VA, Germanà MA. Current and potential use of Citrus essential oils. Cur Org Chem 2013;17:3042-9.

27. Péres VF, Moura DJ, Sperotto AR, Damasceno FC, Caramão EB, Zini $C A$, et al. Chemical composition and cytotoxic, mutagenic and genotoxic activities of the essential oil from Piper gaudichaudianum Kunth leaves. Food Chem Toxicol 2009;47: 2385-9.

28. Almeida CA, Mariana MBA, Francisco CMC, Oliveira MR, Rodrigues IA, Bizzo HR, et al. Piper essential oils inhibit Rhizopus oryzae growth, biofilm formation, and rhizopuspepsin activity. Can J Infect Dis Med 2018;2018:1-7.

29. Schindler B, Heinzmann BM. Piper gaudichaudianum Kunth: seasonal characterization of the essential oil chemical composition of leaves and reproductive organs. Braz Arch Biol Technol 2017;60:1-12.

30. Silva JA, Oliveira FF, Guedes ES, Bittencourt MAL, Oliveira RA. Antioxidant activity of Piper arboreum, Piper dilatatum, and Piper divaricatum. Rev Bras Plantas Med 2014;16:700-6.

31. Telascrea M, Araújo CC, Marques MOM, Facanali R, Moraes PLR, Cavalheiro AJ. Essential oil from leaves of Cryptocarya mandioccana Meisner (Lauraceae): Composition and intraspecific chemical variability. Biochem System Ecol 2007;35: 222-32.

32. Holley RA, Patel D. Improvement in shelf-life and safety of perishable foods by plant essential oils and smoke antimicrobials. Food Microbiol 2005;22:273-92.

33. Oladimeji FA, Orafidiya LO, Okeke IN. Physical properties and antimicrobial activities of leaf essential oils of Lippia multiflora Moldenke. Int J Aromatherapy 2004;14:162-8.

34. Hanamanthagouda MS, Kakkalameli SB, Naik PM, Nagella P, Seetharamareddy HR, Murthy HN. Essential oils of Lavandula bipinnata and their antimicrobial activities. Food Chem 2010;118: 836-9.

35. Monzote L, Scull R, Cos P, Setzer WN. Essential oil from Piper aduncum: chemical analysis, antimicrobial assessment, and literature review. Medicines 2017;4:40-9.

36. Wagner H, Ulrich-Merzenich G. Synergy research: approaching a new generation of phytopharmaceuticals. Phytomedicine 2009; 16:97-10.

37. Coutinho HDM, Costa JG, Lima EO, Falcão-Silva VS, SiqueiraJúnior JP. Enhancement of the antibiotic activity against a multiresistant Escherichia coli by Mentha arvensis L. and chlorpromazine. Chemotherapy 2008b;54:328-30.

38. Azzopardi AEL, Ferguson DW. The enhanced permeability retention effect: a new paradigm for drug targeting in infection. J Antimicrob Chemother 2013;68:257-74.

39. Guimarães DO, Momesso LS, Pupo MT. Antibióticos: importância terapêutica e perspectivas para descobertas e desenvolvimento de novos agentes. Quím Nova 2010;33:667-79.

40. McMurry L, Petrucci RE, Levy SB. Active efflux of tetracycline encoded byfour genetically different tetracycline resistance determinants in Escherichia coli. Proc Natl Acad Sci USA 1980;77: 3974-77.

41. Van Bambeke F, Glupczynski Y, Plesiat P, Pechere JC, Tulkens PM. Antibiotic ef flux pumps in prokaryotic cells: occurrence, im-pact on resistance and strategies for the future of antimicrobial therapy. J Antimicrob Chemother 2003;51:1055-65. 